\title{
GTO サイリスタによる転流制御方式
}

論 文
$59-B 90$

電流形インバータ

$\begin{array}{lllll}\text { 正員 } & \text { 野 } & \text { 作太郎 } & \text { (九州大) } \\ \text { 正員 根 } & \text { 葉 } & \text { 保 彦 } & \text { (九州大) } \\ \text { 准 員 菊 地 } & \text { 健 一 } & \text { (九州大) }\end{array}$

\section{1. まえがき}

電流形インバータにおいて，その代表的な直列ダイ オード方式は，4象限運転が可能，回路構成が簡単で ある,などの特長を有するため, 誘導電動機駆動用と して広く適用されている。しかしながら，ての方式て は，電動機㧊よび負荷の慣性モーメントが比較的小さ い場合に負荷が軽くなったとき，系が不安定になり易 い項问がある。この不安定性は，主として点弧された主 サイリスタに直列のダイオードが，䎐流コンデンサ電 正の影響で逆バイアスされて転流遅机を生じることに 起因するものである。これは，転流コンデンサ容量を 小さく選定することである程度㧕制できるが，反面コ ンデンサ電圧が高くなるので高耐圧の素子が必要之な る。実際の駆動系では，経験的に種々のフィードバッ クをかけて安定化を図っている。筆者らは，直列ダイ オード方式の系の安定化制御方式として，電動機端子 電圧するいは㨁流リアクトル電流の微分值をインバー タゲート回路にフィードバックする方法(1)を示した。 この方法は本質的な回路の不安定性を制御回路で補償 するむのであるため，駆動時では安定性を向上させる が，回生運転時には逆倸を不安定にするととを明ら 加した。また，電動機と並列にダミーリアクトルを 接続することで安定性を向上できる(2)が，インバータ 装置が大形化するき引いがある。その他，直列ダイオ 一ド方式の安定化のため，高速転流を目的として主 サイリスタと並列化転流バイパス回路を接続する方 法(3)(4)や，転流コンデンサ電圧の上昇を抑制するため のクランプ回路の付加(5)などが提案されている。ま

Current Source Inverter with Commutation Control by GTO

Thyristors. By Sakutaro Nonaka, Member, Yasuhiko Neba,

Member \& Kenichi Kikuchi, Associate (Faculty of Engineering,

Kyushu University).

野中作太郎：正圂，九州大学工学部覆気工学科

根葉保产: 正買, 九州大学大学院工学研究科笔気工学専攻

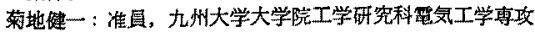

昭 $59-11$
た，負荷の無効電力処理を結合リアクトルで行なう方 法(6)(7)では, 三相電源への電力回生ができない暲点が 范る。

筆者らは, 主回路から直列ダイオードを除去して安 定化を四ることが得策であると判断し，転流コンデン サの充放電を逆並列に接続したサイリスタと転流バイ パス回路で行はう新転流方式電流形インバー夕を提案 した ${ }^{(8)}$ 。更に，波形を改善した改良形新転流方式電流 形インバー夕を開発し(9), 安定性か渄常に良く, 高周 波運転に適することを報告した(10)。

一方，最近では，自己消弧能力有するゲートター ンオフサイリスタ（以下 GTO 上略記）の開発が進み， $2,500 \mathrm{~V} / 1,000 \mathrm{~A}$ 級の素子が製品化されている(11)。 GTO を適用する之, 電圧形インバータでは, 転流回 路が算略可能というメリットにより，既に大容量の GTO が車両駆動装置に応用されている(122。

電流形インバータでも当然，主スイッチング装子と して GTO を用いる回路が考えられるが(13) (15)，無効 電力姏理のため軽流コンデンサを除去するわけにはい 加な。最近，GTO による PWM 方式の正弦波出

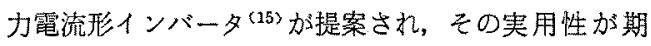
待されるようになった。

今回, GTO を転流制御素子として用い，直列ダイ オード方式に扰ける転流遅れを除去し，枟流コンデン サ電圧の低下，安定性の向上を図った転流制御方式電 流形インバータを開発した ${ }^{(16)}$ 。当然のととながら， GTO はインバータ容量によりパワートランジスタに 置き換えるととができる。とのインバータは，GTO のゲート信号によって，転流コンデンサ電圧を制御で き，誘導電動機駆動特性も良好であることが判明し た(17)-\{21)。

本論文は, 転流制御方式電流形インバータの回路構 成之動作原理について説明し, 誘導電動機駆動特性の 実験結果を示す。次に，誘導機の $V / f$ 一定制御時の 
定常特性解析拉よび電压，電流フィードバック時の安 它解析を行ない，それらの計算と実験結果を直列ダイ オード方式と比較しながら示し，本力式電流形インバ 一タの特長を明らかにする。

\section{2. 回路構成と動作原理}

〈2.1〉回路構成因1亿転流制御方式電流形イ ンバータ主回路と制御回路の構成を示す。Ldは直流 リアクトル, $\mathrm{T}_{1} \sim \mathrm{T}_{5}$ は主サイリス夕， $\mathrm{G}_{1} \sim \mathrm{G}_{6}$ は転 流制御用 GTO, $C_{a} \sim C_{c}$ は転流コンデンサである。 制湖回路は，誘導電動機の端子電圧 $V$ 亡周波数 $f \infty$ 此 V/f を一定とする電圧フィードバックと，系の安 定性向上のための電流フィードバックから战る。フィ ードバックされた電开, 電流の信号格基準信号 $E_{v}{ }^{*}$ 上 比較され，比列積狝制御されてコンバー夕出力電王 $e_{d}$ が決定される。同因で $A_{v}, A_{i}$ は電厈, 電流検出部の 利得で， $K_{i 2}$ はコンバー夕部の利得である。また， $\Delta \tau$

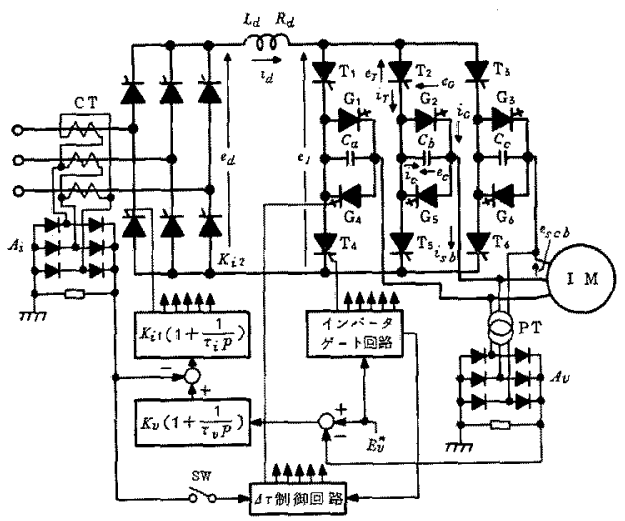

図 1 インバー夕回路

Fig. 1. Inverter circuit.

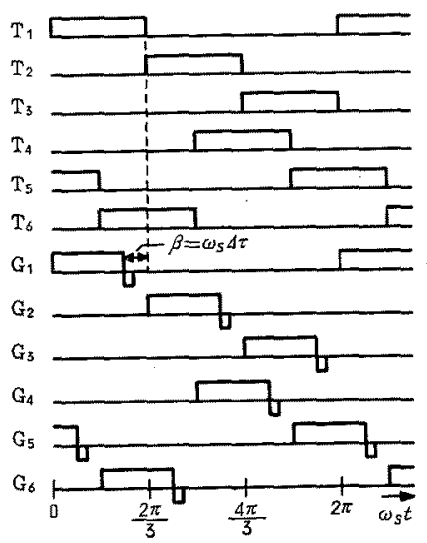

図 2 ゲート信号

Fig. 2. Gate signals.
制御回路は SW がオンの之き，電流フィードバック 信号上インバータゲート回路からの信号により，GTO がオフする時期を決定する。なお，SW か゚オフのとき は，その時期が一定となる。

因 2 に各素子に与えるゲート信昂の波形を示す。 $\beta$ $=\omega s \Delta \tau$ は，例えば $\mathrm{T}_{1}$ と $\mathrm{G}_{1}$ のオン信号の偪の差(電 気角)を表わしている。インバータ主回路において， 二個の GTOが転流コンデンサと並列に接続されてい るので，どちらか一方のGTOか導通状態の上き，耺 流コンデンサは㛒絡状態である。诖って，GTOのオ フのタイミング, すなわち园2 に示される $\Delta \tau$ を変え るととにより，転流コンデンサの充電時聞つまりその 電仕を制御できる。

〈2.2〉動作原理本方式インバータの回路動作

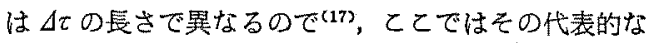
動作について説明し，軽流は $T_{1}$ 加ら $T_{2}$ につて考 える。

図 3 は $\Delta \tau=0$ の場合の回路動作である。 $\mathrm{T}_{1}, \mathrm{G}_{1}$, $\mathrm{T}_{6}, \mathrm{G}_{6}$ が導通しているとき, $\mathrm{T}_{2}, \mathrm{G}_{2}$ にオン信号， $\mathrm{G}_{1}$ にオフ㛿号を与えると， $\mathrm{G}_{1}$ はオフするが $\mathrm{T}_{1}$ は $C_{a}$

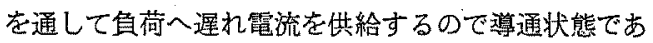
る。また， $G_{2}$ は $C_{b}$ が前の転流で右側が正に充電さ れているので, 逆バイアスされてオンせず，図 3(a) の重なり期間となる。 $a$ 相電流が $C_{a}$ を充電しながら 减少するにつれて， $C_{b}$ が放電して $b$ 相電流は增加す る。この状態で， $C_{b}$ の電正が零になると， $\mathrm{G}_{2}$ がオン して図 3(b)の転流コンデンサ充電期間上なる。その 後， $a$ 相電流が零になり $T_{1}$ がオフして 転流は完了 する。とのような回路動作をモードA と定姜する。

因 4 は、 $\Delta \tau$ が存在し比較的長い場合の動作である。 重なり期間住 $3(a)$ 上同じであるが， $T_{2}$ オンの前 にすでに $\mathrm{G}_{1}$ がホフされているため，モードAのとき

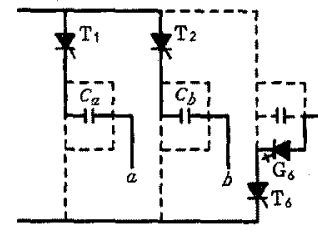

(a) 亘去方期間

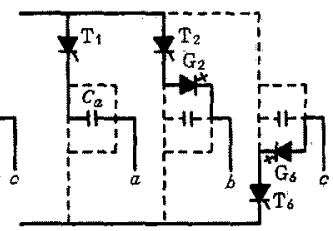

(b) 枟流コンデンサ充電期間

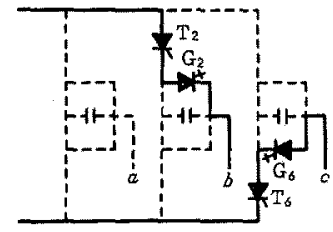

(c) 些流䩗間
图 3 回路動作

(モードA)
Fig. 3. Circuit operations (mode A). 


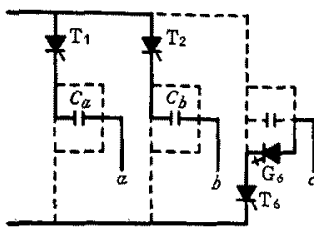

(a) 重去b期間

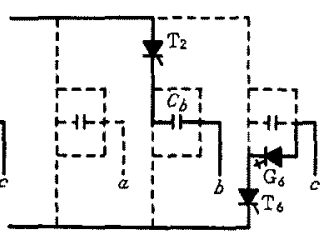

(b)而流コンデンサ放笔期間

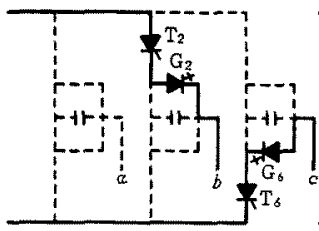

(c) 单流期間

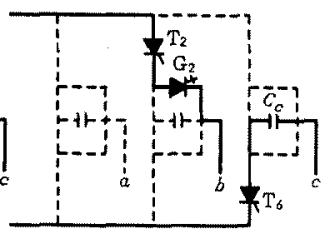

(d) 予诺光電期間
议 4 回路動作 (モード $\left.B^{\prime}\right)$

Fig. 4. Circuit operations (mode $B^{\prime}$ ).

より転流コンデンサ電任が高くなる。従って，Cb の放 電が終わる前に $a$ 相電流が零となり，T1 がオフして 図 4 (b) の軽流コンデンサ放電期間に移る。その後, $C_{b}$ の電王が零となり単流期間となる。更に，この場

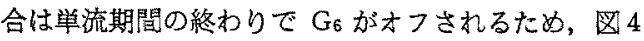
(d)に示す予䧿充電期間が $\Delta \tau$ の時間存在する。この 回路動作をモード $\mathrm{B}^{\prime}$ と定義し， $\Delta \tau \neq 0$ の場合にはダ ッシュを付けて衰わす。また，モード $A^{\prime}$ ，あるいは $C_{b}$ の電生が零になると同時に $a$ 相電流が零になる動作 あ起こるが，その範囲は狭い(19)。乙の上うに，予備充 電期間の長さで転流コンデンサの充電時閻が変えられ るので，結果として，その電王を制御できるととにな る。上記のように，本力式は GTO のオフによりコン デンサと刍荷との共振回路を形成し，その其振電流で 主サイリスタ電流を消滅させて䎐流を行なう方式であ る。 $\Delta \tau$ を短く設定すると，コンデンサ電王が低下し て軽流時間が長くなり，次の転流開始時までに主サ1 リスタがオフせず転流失敗に陷る。従って，本方式で は回路㧍よび笔動機定数を十分考虑して $\Delta \tau$ を決める 必要がある。インバー夕周波数 $60 \mathrm{~Hz}$, コンデンサ容 量 $10 \mu \mathrm{F}$ で無負荷時には $\Delta \tau$ は $300 \mu \mathrm{s}$ 以上必要であ るが, この值はコンデンサ容量および電動機定数で異 なりまた，周波数の低下るるいは，すへりの堌加に 伴って短くすることができる。

\section{3. 誘導機駆動特性}

表 1 に示す定数をむつ三相誘導電動機をインバータ 周波数 $60 \mathrm{~Hz}$ ，端子電生実效值 $200 \mathrm{~V}$ で運転した場合 の各部の実测波形を図 5 亿示す。园で $e_{I}$ アは淔流少 クトル出力電圧, $i_{a}$ は㨁流リアクトル電流, $i_{\text {b }}$ は誘 導機相電流, $e_{s c b}$ は端子電圧, $e_{C}$ は転流コンデンサ雪
表 1 電動機およびインバータ定数

Table 1. Machine and inverter constants.

\begin{tabular}{|c|c|}
\hline 軋動機定数 & インバータ定数 \\
\hline $2.2 \mathrm{~kW}$ & $L_{d}=0.224 \mathrm{H}$ \\
\hline $200 \mathrm{~V}$ & $R_{d}=0.885 \Omega$ \\
\hline $60 \mathrm{~Hz}$ & $C=10_{\mu} \mathrm{F}$ \\
\hline$P=4$ 極 & $A_{0}=0.03$ \\
\hline$r_{s}=0.859 \Omega$ & $A_{i}=0.3$ \\
\hline$r_{r}=0.459 \Omega$ & $K_{v}=1$ \\
\hline$L_{s}=L_{y}=0.0904 \mathrm{H}$ & $K_{i}=K_{i 1} K_{i 2}=200$ \\
\hline$M=0.0873 \mathrm{H}$ & $\tau_{\varepsilon}=0.2$ \\
\hline $\begin{array}{l}J=0.0179 \mathrm{~kg} \cdot \mathrm{m}^{2} \\
\quad \text { （負荷用の直流機を含む） }\end{array}$ & $\tau_{i}=0.022$ \\
\hline
\end{tabular}

王である。ecは回路動作からわかるように，並列に接 続された GTO がオンしている聞は零であるので $60^{\circ}$ 幅の方形波となる。図5(a) と(b)は，無負荷時 $(s=$ $0.28 \%)$ および真荷時 $(s=3.2 \%)$ で，両者とも $\Delta \tau=$ $300 \mu \mathrm{s}$, モード $\mathrm{B}^{\prime}$ である。図 $5(\mathrm{c})$ 愪荷時で $\Delta \tau=0$ とした場合で、モードAの動作である。負荷時では， $\Delta \tau=300 \mu \mathrm{s}$ のとき, $e_{C}$ が高くなるので䎐流時間が短 くなり, escb のスパイクが大きくなる。しかし、 $\Delta \tau$

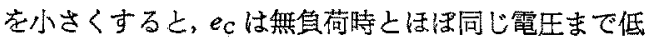
くなり，escbのスパイクが小さくなる。また， $e_{1}$ の波 形のひずみす小さくなる。主サイリス夕電流 $i_{T}$ は。 GTO 電流 $i_{G}$ 之転流コンデンサ電流 $i_{C}$ の和であり， 主サイリスタ電圧 $e_{T}$ は, 転流コンデンサ電圧と端子 笪代の和となる。このように，GTOは転流用補助素 子であるが，単流期間ではGTO を通して負荷電流が 流れるため、主サイリスタと同等の電流容量を有する あのが必要である。

実駼回路に使用した GTO は逆耐圧を有しないの で，逆電圧阻止を目的として，ダイオードを各々の GTO 之直列に接続している。図5 (c)の GTO 電圧 $e_{G}$ は，このダイオード李含めた波形で $e_{\mathrm{C}}$ と同じであ る。ただ，このようなダイオードの付加は回路動作に 対して影響を与えるむのではないので，图1では図示 を省略した。

図6に本方式および直列ダイオード方式の転流コン デンサ電王特性の実測値, 因 7 に $\Delta \tau>$ フードバック 時のすべりに対する $\Delta \tau$ の変化を示す。四6に扔いて 直列ダイオード方式は転流コンデンサが 結線で 1 個 の容量が $C=10 \mu \mathrm{F}$ の場合の特性である。本方式では $\Delta \tau=300 \mathrm{~s}$ 一定の場合，すべりが大きくなるにつれて $e_{C}$ は高くなる。しかし， $\Delta \tau$ 制御時 ${ }^{(20)}$ では，すべり とともにコンデンサの充電期間が短くなるので, $e_{C}$ は 直列ダイオード方式に比べてかなり焦い植に保たれる ようになる。このように, 負荷状態に岕じて $\Delta \tau$ を変 化させれば $e_{C}$ の上异は抑元られるが， $\Delta \tau$ の値は2 


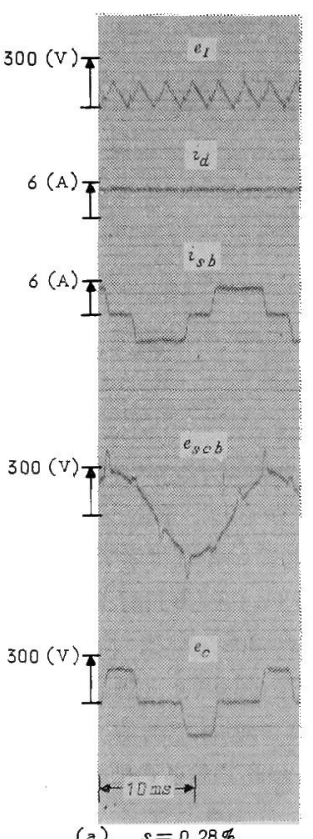

(a) $\begin{aligned} s=0.28 \% \\ \Delta \tau=300 \mu s\end{aligned}$

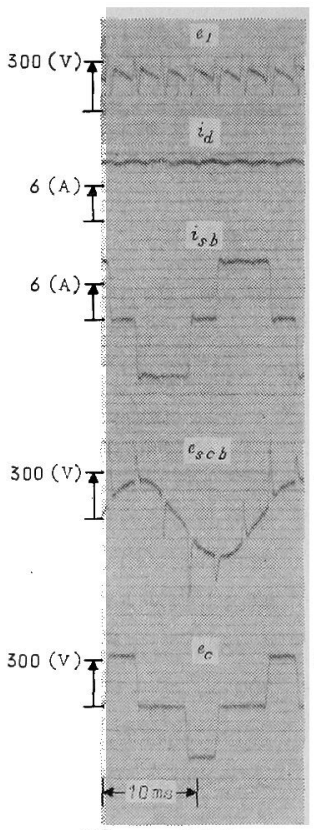

(b) $s=3.2 \%$

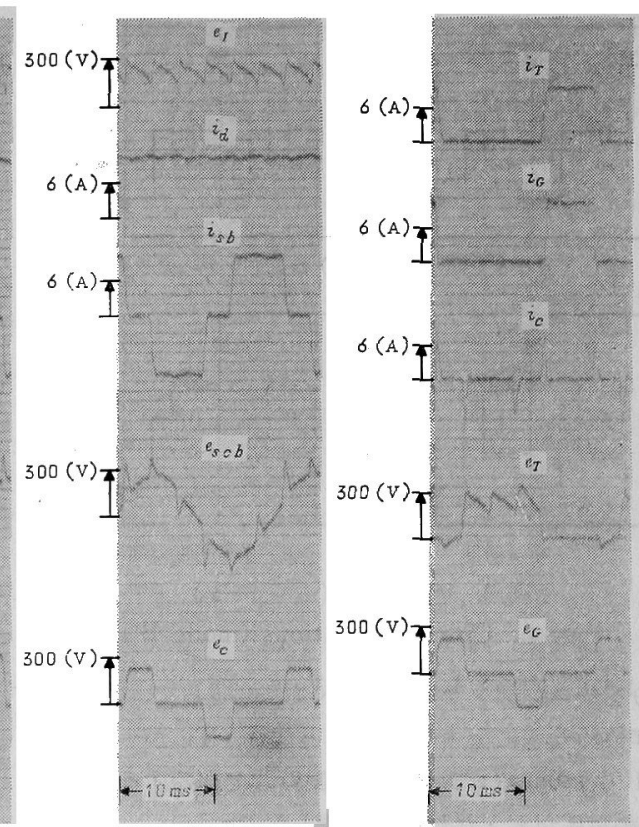

(c) $s=3.2 \% \quad \Delta \tau=0$

図 5 実験波形

Fig. 5. Experimental waveforms.

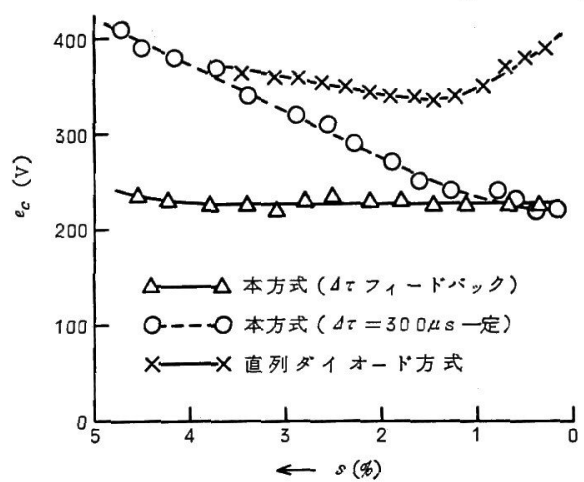

図 6 転流コンデンサ電圧特性

Fig. 6. Commutating capacitor voltage characteristics.

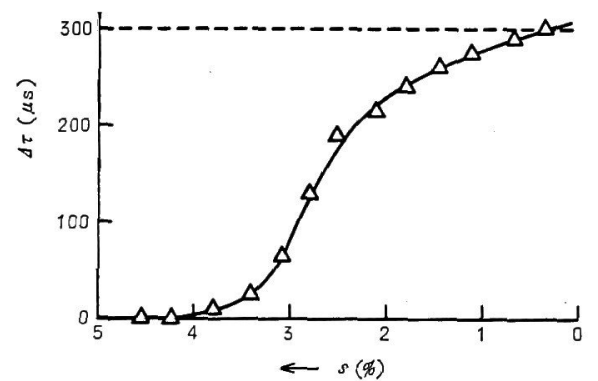

図 7 すべりに対する $\Delta \tau$ の变化

Fig. 7. Variation of $\Delta \tau$ for slip.

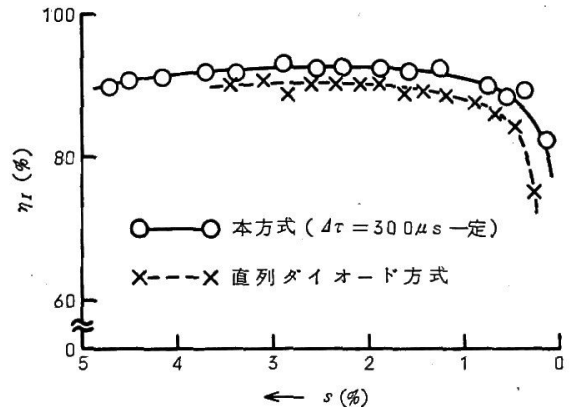

図 8 インバータ効率特性

Fig. 8. Inverter efficiency characteristics.

節で述べた原因で起こる転流失敗に至らない範团で制 御する必要がある。また，乙こでは図示を省略したが インバータ周波数に対しても $\Delta \tau$ が変化するように制 御を行なっている。

因 8 にすべりに対するインバータ效率特性を示す。 効率は, インバータ入力電圧 $E_{d}$, 直流電流 $I_{d}$, およ び電動機入力電力 $P_{i}$ の実测値より $P_{i} /\left(E_{d} \times I_{d}\right)$ 之 して計算した。なお，電圧スパイクなどによる計測器 の就差が本方式と直列ダイオード方式とも同じである とした。本方式は直列ダイオード方式より $2 \sim 5 \%$ 良好である。乙れは，導通素子の順方向電圧降下によ る損失は直列ダイオード方式と同等であるので，転流 
コソデンサ電氏による転流損失の差によるすのと考え られる。また，本方式では， $\Delta \tau$ が短い方がわずかで あるが効率が向上する。

\section{4. 定常解析と計算結果}

〈4-1〉解析方法 解析に際して，コンバータの

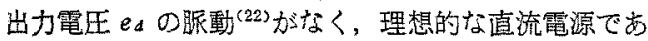
ると仮定し， $a$ 相加ら $b$ 相への梳流，すなわち， $\mathrm{T}_{2}$ がターンオンしてから T 4 をオンする值前までの $\mathrm{T}=$ 1/(6f) の区間考兑る。本方式の回路敛作モード $B^{\prime}$ について考えると、重なり，䎐流コンデンサ放電，单 流，予備充電期間から構成され，各期間の等価回路は 図90ようになる。解析は状態变数法(23)を用い，この ときの状態変数 $\boldsymbol{x}$ を次のように選ぶ ${ }^{(18)}$ 。

$$
x^{T}=\left[E_{d}, i_{d}, i_{c a}, e_{c a}, e_{c b}, e_{c c}, \phi_{r d}, \phi_{r q}\right]
$$

$\phi_{r d}, \phi_{r q}$ は回転子の $d$ 軸， $q$ 朝磁束銷交数である。 インバータ誘導電動機系の备期間の状態方程式は,

$$
p \boldsymbol{x}(t)=\boldsymbol{A}_{i} \boldsymbol{x}(t)(i=1,2,3,4)
$$

上表わされる。但し，重なり期間での囷数行列 $\boldsymbol{A}_{1}$ は 誘導機の一次执上び二次目己インダタタンスをL、 $L_{r}$ ，励磁インダクタンスを $M$ ，一次书よび二次抵抗を $r_{s}, r_{r}$ とすると次の様になる。

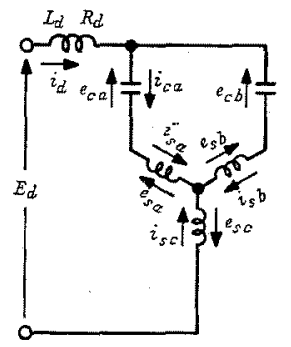

(a) 重索可期間 $\left(0<t \leqq \tau_{1}\right)$

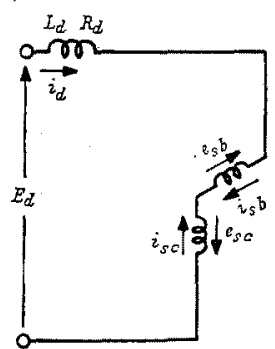

(o) 単流期間 $\left(\tau_{2}<t \leqq \tau_{3}\right)$

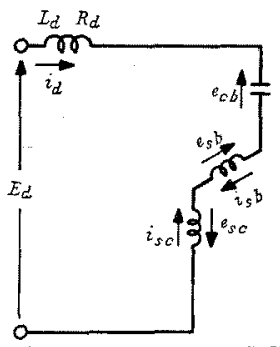

(b) 西流コンデンサ放電期間 $\left(\tau_{1}<t \leqq \tau_{2}\right)$

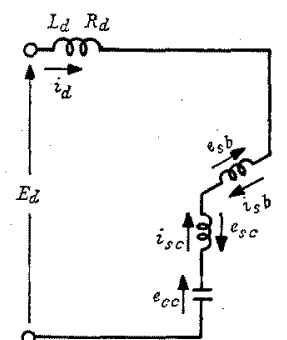

(a) 予菕充電期間 $\left(\tau_{3}<t \leqq T\right)$
图 9 等洒回路 $\left(モ-ト ゙ B^{\prime}\right)$

Fig. 9. Equivalent circuits (mode $B^{\prime}$ ).

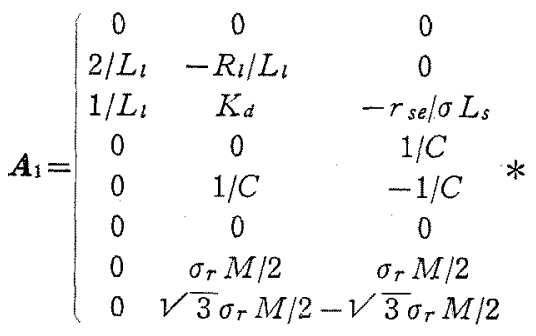$$
\begin{array}{cccc}
0 & 0 & 0 & 0 \\
-1 / L_{l} & -1 / L_{l} & 0 & M\left(3 \sigma_{r}-V \overline{3} \omega_{r}\right) / L_{l} L_{r}
\end{array}
$$$$
K_{c} \quad K_{c}^{\prime} \quad 0 \quad K_{\omega} \sigma_{r}+K_{\sigma} \omega_{r}
$$$$
\text { * } \begin{array}{rrrrr}
0 & 0 & 0 & 0
\end{array} \text { * }
$$$$
\begin{array}{llll}
0 & 0 & 0 & 0
\end{array}
$$$$
\begin{array}{lllll}
0 & 0 & 0 & -\sigma_{r}
\end{array}
$$$$
\begin{array}{llll}
0 & 0 & 0 & \omega_{r}
\end{array}
$$

$$
\left.\begin{array}{c}
0 \\
M\left(\sqrt{3} \sigma_{r}+3 \omega_{r}\right) / L_{l} L_{r} \\
K_{\omega} \omega_{\tau}-K_{\sigma} \sigma_{r} \\
0 \\
0 \\
0 \\
-\omega_{r} \\
-\sigma_{r}
\end{array}\right)
$$

ここで,

$$
\begin{aligned}
& \sigma_{r}=r_{r} / L_{r}, \sigma=1-M^{2} / L_{s} L_{r} \\
& r_{s e}=r_{s}+(1-\sigma) L_{s} \sigma_{r}, \omega_{r}=2 \pi f(1-s) \\
& R_{l}=2 R_{d}+3 r_{s e}, L_{l}=2 L_{d}+3 \sigma L_{s} \\
& K_{c}=-\left(L_{d}+2 \sigma L_{s}\right) / \sigma L_{s} L_{l} \\
& K_{d}=\left(L_{d} r_{s e}-R_{d} \sigma L_{s}\right) / \sigma L_{s} L_{l} \\
& K_{s}=M\left(L_{d}+3 \sigma L_{s}\right) / \sigma L_{s} L_{r} L_{l} \\
& K_{c}=\left(L_{d}+\sigma L_{s}\right) / \sigma L_{s} L_{l} \\
& K_{\sigma}=\sqrt{3} M\left(L_{d}+\sigma L_{s}\right) / \sigma L_{s} L_{r} L_{l}
\end{aligned}
$$

また，予備充電期間加ら次の区間 $T$ 八移るときに は，接続厅列 $B$ ，を用いて次式て接続する。

$$
\boldsymbol{x}\left(T_{+}\right)=\boldsymbol{x}\left(0_{+}\right)=\boldsymbol{B}_{c} \boldsymbol{x}\left(T_{-}\right)=\boldsymbol{B}_{c} \boldsymbol{x}\left(0_{-}\right) \ldots(3)
$$

重なり釉了時間を $\tau_{1}$, 転流コンデンサ放電終了時間 を $\tau_{2}$ とすると，重なり期間加ら転流コンデンサ放電 期間扢よび転流コンデンサ放電期間から単流期間への 選移条件は，それぞれ次式で与えられる。

$$
i_{c a}\left(\tau_{1}\right)=0, \quad e_{c b}\left(\tau_{2}\right)=0
$$

上式より

$$
\Gamma_{1}^{T} \boldsymbol{x}\left(\tau_{1}\right)=0 \ldots(4), \quad \Gamma_{2}{ }^{T} \boldsymbol{x}\left(\tau_{2}\right)=0 \ldots(5)
$$

ここで,

$$
\Gamma_{1}{ }^{T}=(0,0,1,0,0,0,0,0], \Gamma_{2}^{T}=[0,0,0,0,1,0,0,0\}
$$
槊流期間加ら予備充電期間八の遥移は, 時間 $\tau_{3}$ で強 制的に行なわれるので，条件は $t=\tau_{3}$ である。 
(2)〜 (5) 式より， $\tau_{3}$ は既知であるので，末知数 $\boldsymbol{x}(0-), \tau_{1}, \tau_{2}$ 亿関する 10 元非線形連立方程式を作り ニュートン法を適用して数值計算を行なった。

$\Delta \tau=0$ の場合には，eck関する成分を零とするか $e_{a c}$ を取り除いて考え， $\tau_{3}=T$ とすれば全く同㥞な解 析法で行なうこよができる。

〈4・2〉解析結果＼cjkstart計算仁用いた電動機およびイ ンバータ定数は表 1 亿示す通りである。

図 10 亿無急荷時, $\Delta \tau=300 \mathrm{ks}$ での各部の計算波形 を示す。祀は瞬時トルクである。 $\mathrm{T}_{2}$ オン $(t=0)$ と 同時に相電流 $i_{s a}$ 方減少し重なり期間となる。端子電 王 $e_{s b a}$ のスパイクは, 転流コンデンサ電圧と相電流 変化時に電動機の漏れインダクタンスに誘起される電 压の和である。また，予備充電期間が存在するので， 転流コンデンサ電圧 $e c$ は $t=0$ で約 $140 \mathrm{~V}$ から充電 加始まっている。 $e_{T}$ 波形において，主サイリス夕夕 ーンオフ直後の逆バイアス電圧は電動機端子電圧之軽 流コンデンサ電王の和であり， $e_{C}$ の変化によって, ての電圧す变化する。従って, 前述したようにての逆 バイアス電圧を考虑して $\Delta \tau$ 決める必要がある。し かし, 負荷時では電動機端子電圧で逆バイアスされる ため[図 $5(\mathrm{c})$ 参脕]， $\Delta \tau$ は必ずし6必要ではない。 軽負荷時での主サイリスタの逆バイアス時間は転流コ ンデンサ容量と電動機漏れインダクタンスに依存し,

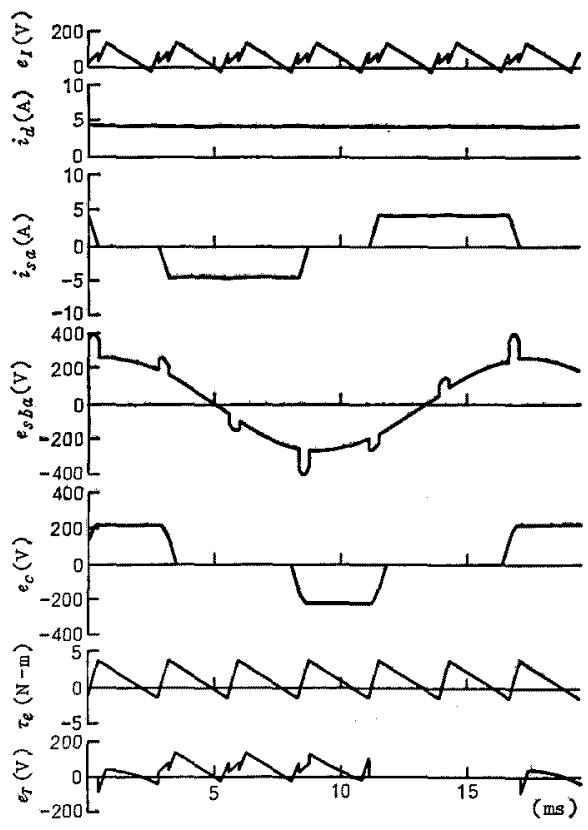

因 10 計算波形 $(s=0.28 \%, \Delta \tau=300 \mu \mathrm{s})$ Fig. 10. Calculated waveforms.

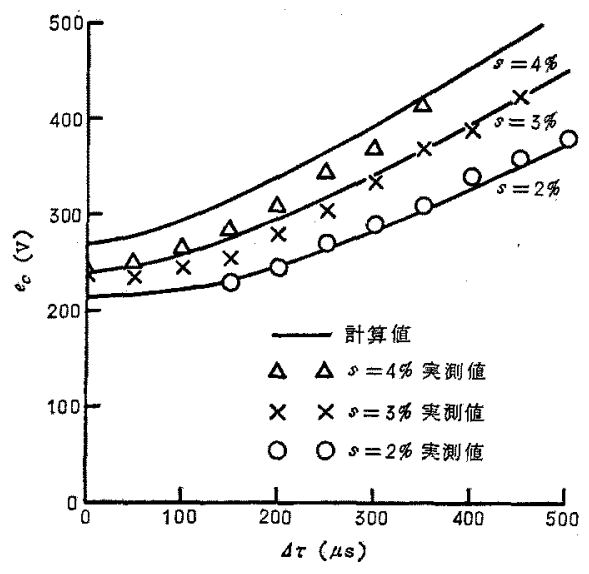

図 $11 \Delta \tau$ に対する転流コンデンサ筐王特性 Fig. 11. Commutating capacitor voltage characteristics for $\Delta \tau$.

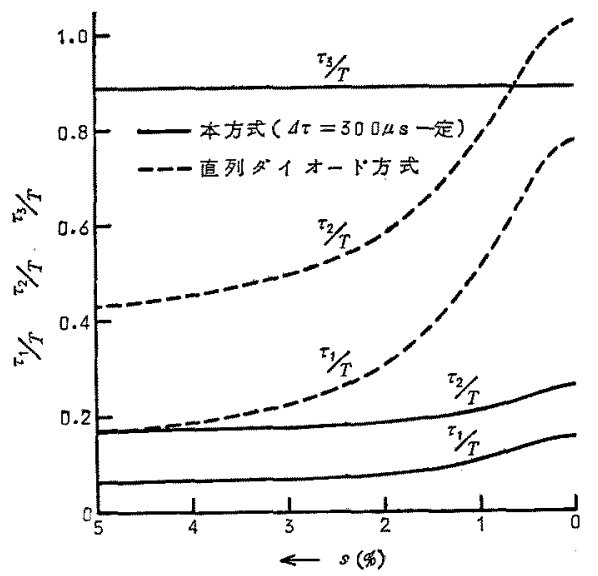

园 12 転流時間特性

Fig. 12. Commutating time characteristics. $C=10 \mu \mathrm{F}$ で約 $200 \mu \mathrm{s}$ である。各部計算波形は，図 5 (a)の実測诐形と比較して，形状および大きさともよ く一致している。

图 11 亿各すべりに対して， $\Delta \tau$ を变化した場合の 転流コンデンサ電圧特性の計算掞よび実测值を示す。 两者とも $\Delta \tau$ の增加につれて転流コンデンサ電圧は高 くなる。すべりが大きいほど $e_{C} の \Delta \tau$ に対する上昇 率が大きいのは，電陲機相電流がすへりと共に增加す るためであり，計算と实測はほぼ一致している。

図 12 は本方式および直列ダイオード方式の転流時 間特性の計算值である。直列ダイオード方式において $\tau_{1}$ は逆バイアス終了時間， $\tau_{2}$ は重なり終了時間宗 す。本方式の転流時間 $\tau_{1}$ は，直列ダイオード方式の 約 15\%であり，非常に短いととがわかる。 


\section{5. 安 定 性}

転流制御方式電流形インバータ駆動誘導電動機系の 安定性の考察において, 困 1 亿示される電圧, 電流の 比例皘分制御フィードバック (1)を考える。解析は定常 解析之同じ $\Delta \tau=300 \mu \mathrm{s}$, 回路動作モード $\mathrm{B}^{\prime}$ について 行なう。従って, 系の状態変数および各期間の状態方 程式は(1)と(2)式で与えられる。

いま, $J$ を慣性モーメント， $T_{L}$ を負荷トルクとす ると，機械系の運動方程式は次式で表执れる(24)。

$$
p \omega_{r}(t)=\frac{P}{2 J}\left\{\boldsymbol{x}^{T}(t) \boldsymbol{D} \boldsymbol{x}(t)-T_{L}\right\}
$$

困1より,フィードバックに対する式は，

$$
\begin{aligned}
e_{d}= & K_{i}\left(1+\frac{1}{\tau_{i} p}\right)\left\{K_{v}\left(1+\frac{1}{\tau_{v} p}\right)\right. \\
& \left.\times\left(E_{v}{ }^{*}-A_{v} E_{s}\right)-A_{i} I_{d}\right\}
\end{aligned}
$$

となり，Eは電動機端子電圧の全波整流値， $I_{d}$ は 直 流電流の平均值である。

ここで, 次式で与えられる変数 $Q_{1}, Q_{2}$ を考える(2)。

$$
\begin{aligned}
& p Q_{1}=\frac{K_{v}}{\tau_{v}}\left(E_{v}{ }^{*}-A_{v} E_{s}\right) \ldots \ldots \ldots \ldots \ldots \ldots(8) \\
& p Q_{2}=\frac{K_{i}}{\tau_{i}}\left\{K_{v}\left(E_{v}{ }^{*}-A_{v} E_{s}\right)+Q_{1}-A_{i} I_{d}\right\}
\end{aligned}
$$

従って,（7)式は次のようになる。

$$
\begin{aligned}
e_{d}= & K_{i}\left\{K_{v}\left(E_{v}^{*}-A_{v} E_{s}\right)+Q_{1}-A_{i} I_{d}\right\} \\
& +Q_{2} \ldots \ldots \ldots \ldots \ldots \ldots \ldots \ldots \ldots \ldots \ldots \ldots \ldots \ldots \ldots \ldots \ldots \ldots \ldots \ldots \ldots \ldots
\end{aligned}
$$

（8）（10)式を周期 $T$ のサンプル值表示をし，徽小 変動分をとり, 新たに状態変数を

$$
\boldsymbol{y}^{r}=\left[\boldsymbol{x}^{T}, Q_{1}, Q_{2}, \omega_{r}\right]
$$

因 13 代表根の 軌跡 $(J=0.0179$ $\left.\mathrm{kg}-\mathrm{m}^{2}\right)$

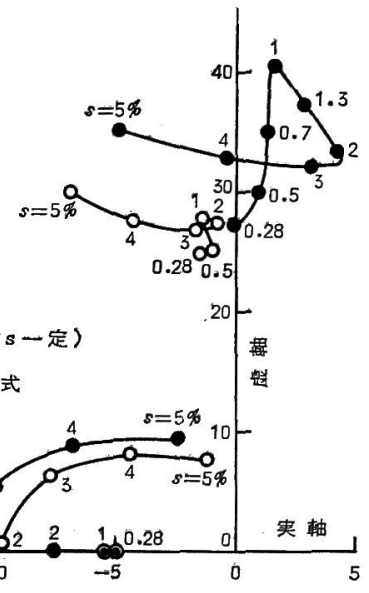

Fig. 13. Loci of dominant roots.
図 14 代表根の 軌跡 $(J=0.1 \mathrm{~kg}$. $\left.\mathrm{m}^{2}\right)$

○本方式（ $\Delta \tau=300 \mu \mathrm{s}$ 一定）

值列ダイオード方式

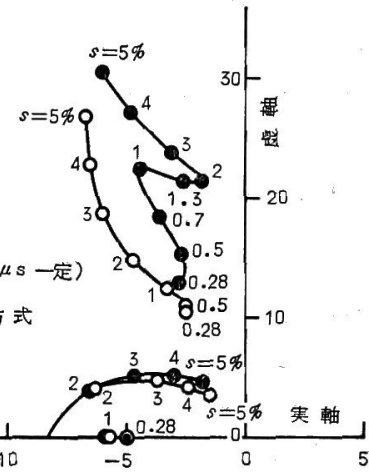

Fig. 14. Loci of dominant roots.

とすると次式を得る。

$$
\Delta \boldsymbol{y}(k T+T)=\boldsymbol{H} \Delta \boldsymbol{y}(k T)
$$

(11)式に打いて, 行列 $\boldsymbol{H}$ の固有值を求めることによ り系の安定判別ができる。

図 13 k $f=60 \mathrm{~Hz}, C=10 \mu \mathrm{F}, J=0.0179 \mathrm{~kg}-\mathrm{m}^{2}$ で の本方式および直列ダイオード方式のすべりに対する 代表根の軌跡を示す。直列ダイオード方式は回路動作 が A モード (25) としたときの根である。同図より，電 E，電流フィードバック時において，慣性モーメント が小さい場合直列ダイオード方式では軽負荷時で不安 定な根が現れているが，本方式はすべて安定であるて とがわかる。実験代おいても本方式は不安定性が現れ

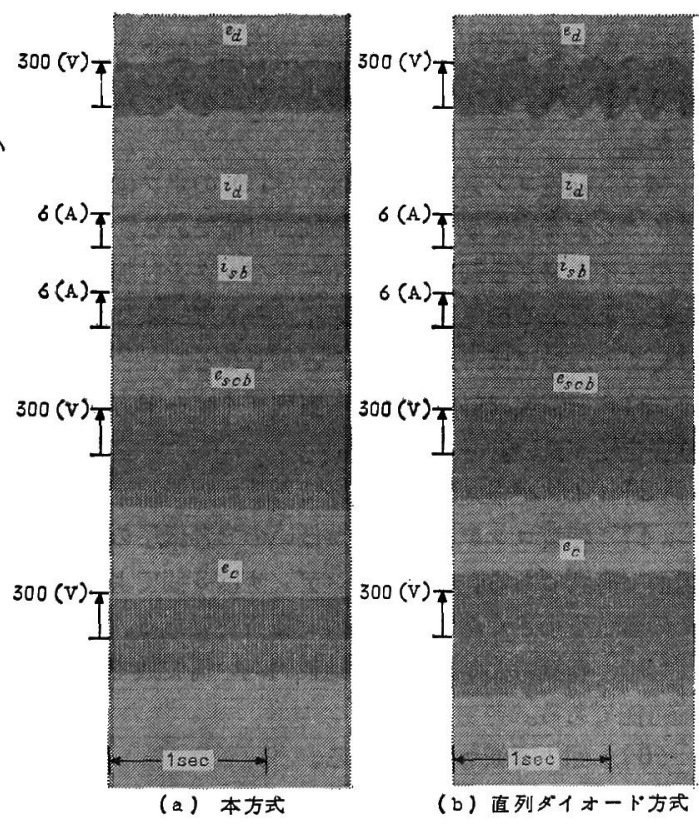

因 15 ステップ芯答

Fig. 15. Step responses. 
ないことを確認している。軽負荷時の根の動きは開ル

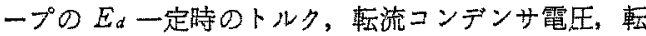
流時闒特性に関伱があり，本方式の根の動きが少ない のは図 12 に示すように，すべりに対して耺流時間か ほとんよ゙変わらないためと考えられる。

図 14 に $J=0.1 \mathrm{~kg}-\mathrm{m}^{2}$ の場合の代表根を示す。慣 性モーメントが大きくなると，本方式の根は直列ダイ オード方式と同様に更に安定侧へ移行し，角周波数も 低下する。

図 15 は $s=0.28 \%$ から $0.44 \%$ へのステップ応答 時の各部の実测波形である。直列ダイオード方式では 真荷投入後, 各波形は振動し不安定であるが，本方式 では直ちに淢衰して安定であることがわかる。これら のととは，図 13 の結果と一致している。

\section{6. まとめ}

以上，本論文で提案した転流制御方式䉓流形インバ 一夕は，GTO定転流制晸用として用いるととにより， 従来の直列ダイオード方式とは全く異った回路動作で 軽流を行なう方式であり，その有用性を誘尊電動機駆 動時の実験から明らかにした。また，状態変数法で定 常解析を行ない，各部計算波形が実測值と非常によく 一致することを確認した。更に，本方式の電流形イン バータで誘導電動機を駆勳する場合の系の安定性につ いて検討した。てれらの実驗战よび計算結果より，本 方式電流形インバータは，周波数および電勳機の負荷 状態に応じて GTOのオフ時期を適切に制御する必要 があるが，次のような特長を有するこ上が明らかとな った。

（1）転流コンデンサ電Eは，GTO のオフ信号の タイミングを变えることにより制御可能である。また このタイミングを制御するフィードバックを付加する ことにより，乙の電壬を直列ダイオード方式よりかな り低く，かつは沽一定に保つことができる。

（2）低慣性，軽真荷時です直列ダイオード方式よ り安定性が良い。

(3)インバータ効率は良好である。

（4）転流コンデンサ䉓压が低いので各素子の耐王 の面で有利である。また，コンデンサは 3 個でよく， その容量を小さく選定できるので経済的である。

（5）䎐流時間力゙短いので比较的高い周波数でも運 転可能である。

（6）回生運転も可能である。

従って，本方式の電流形インバータは誘導電動機駆

動用などに十分実用性があると考えられる。

終りに，本研究に有益なで助言，で討議を頂いた九

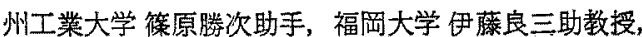
また，実験にご協力頂いた本学 光安誼生技官に深く謝 意を表する。

（昭和58年12月26日受付，同59年 7 月13日再受付）

$$
\text { 文献 }
$$

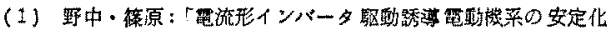
制御方式の検討」電学諭 B 102，9 (昭 57-1)

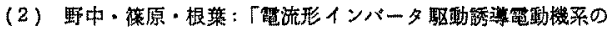
ダミーリアクトル考清時の定常および安定性」昭 57 電気学 会全大 No. 563

（3）富崎・杉本・長南・棤山・田中：「交流要野機のインバータ

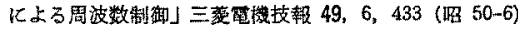

（4）杉本・田中：「标流バイパス回路を湖えた電流形インバータ

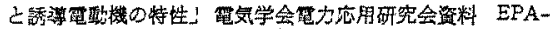
75-7 (昭 50-8)

(5) R. Palaniappan \& J. Vithayathil: "High-Frequency Current Source Inverter", IEEE Trans. Indust. Appl. IA16, 3, 431 (1980)

（6）金・黑沢：「結合りアクトル捏流法之電流形インバータ」四 学諭 B 96，391 (昭 51-8)

（7）村井・鈴木・常広: 「転流方式を改善した䉓流形インバータ ヒついて」管学諭B 99, 729 (罗 54-11)

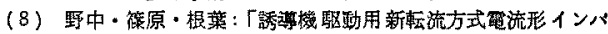

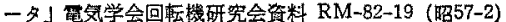

(9) K. Shinobara \& S. Nonaka: "Current Source Inverter with a New Commutation Circuit", IPEC-Tokyo. 608 (1983)

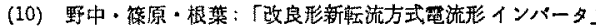
学綸 B 103, 101 (昭 58-2)

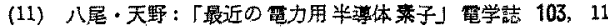
(昭 58-1)

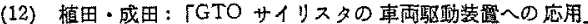
昭 58 视気学全全大 S. 5-2

(13) 伊绿・石坂・野中:「コンデンサバイパス方式 GTO 電流瓶

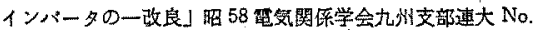
313

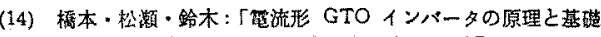
特性」笔気学会半導体笔力变換研究会签料 SPC-83-21 (昭 $58-8)$

(15) 本部・上田・松田：「正弦波出力電流形 GTO インバータ」

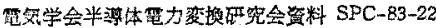

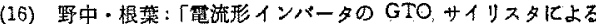
枟流制梅昭 57 電気四学会九州支部逨大 No. 449

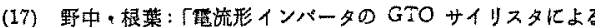

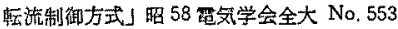

（18）野中・根菜・菊地：「GTOサイリス夕社流制御方式電流形イ

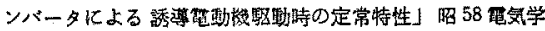
会全大 No. 554

(19) S. Nonaka \& Y. Neba : "Commutation Control of Current Source Inverter Using GTO Thyristors", $3 r d$. IFAC Symposium. 209 (1983)

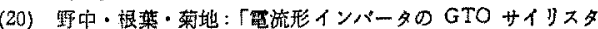
に上る枟流コンデンサ笔王制御」昭 58 電気関㐿学会九州支 部連大 No. 315

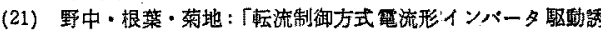

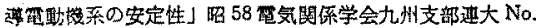
316

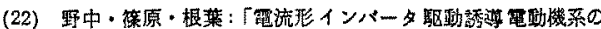
ビート現象」菷学猃B 102，521 (昭 57-8)

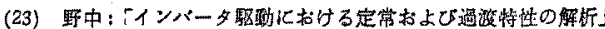
昭 53 需気学会全大 S. 7-7

（24）野中・伊藤：「直列ダイオード方式䉓流形インバー夕駆動誘

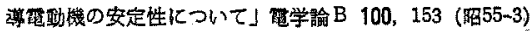

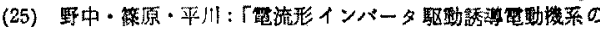

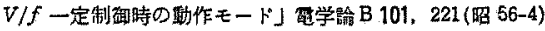

